\title{
The Relationship between Digital Image Processing and 21st century European Union Regulation of Land Policy
}

\author{
Réka Bokor dr. \\ The Institute of Geography and Earth Sciences of the University of Pécs, Budapest, Hungary \\ bocorreca@gmail.com
}

\begin{abstract}
Currently there is no common land policy regulation between the European Union and its Member States, which can create a public interest in supporting and sustaining the agricultural community, as well as small and medium-sized farms, and promoting the survival of rural populations.

In order for legal and economic determinants to move closer and be accepted uniformly in the Member States of the European Union, a common position should be reached.

One of the major and typical units of the economic and social system of our 21 st century is digital information that provides up-to-date and accurate data directly to the user through ICT devices. The question arises then as to how we should deal with the problems not resolved so far in our digital society with the tools used daily in our digital age.

An alternative solution could be provided by the field of digital image processing, which can record not only numerical data to supplement the regulation of land policy, but also visual state assessments and processes by completing metadata databases and by providing continuous access to spatial data for related professionals.

However, it is imperative to provide training and further education for related professionals with ICT devices, through which employees of the sectors concerned can gain new competencies.

This research examines output results of digital image processing tools as a function of community interest approximation by target-oriented training of the required professionals.
\end{abstract}

Keywords: digital image processing, geopolitics, land policy regulation, metadata database, ICT tools, iMezö

\section{INTRODUCTION}

My field of research is the examination of land use and property (land policy) regulations based on different geographic conditions in the light of EU regulations. The assumption is that the randomly selected EU Member States, located in various parts of the continent (Denmark - North, France - West, Spain - South, Hungary - East) have different geographic features (climate, terrain, soil, hydrography, flora, fauna, etc.) which fundamentally influence the production, the species/varieties and quantity of crops and animals, i.e.: the structure of agriculture. The agricultural structure of agricultural land is the basis of land policy regulation, i.e.: the land use and property ownership regulations of the Member States. The selected Member States are all members of the European Union, so their regulators should be examined from the perspective of EU Common Agricultural Policy (CAP) principles and guidelines, support and management regulations, as the conditions of EU funding and the European Commission's infringement proceedings against the Member States may be the reason for the regulation that is violating them. It is well-known that Hungary (and the newly acceded Member States) after having joined the EU, gained a benefit (derogation) which meant a grace period of seven plus three years for newly acceded Member States to set up their land policy regulators in line with EU requirements.

\section{About EU Regulation}

The exclusive national land-use identification system, result of digital image processing (orthophotos), established by the Union for granting and controlling area-based agricultural subsidies to the Member States is the Mezögazdasági Parcella[1] Azonositó Rendszer (MePAR, Agricultural Parcel Identification System). The identification of agricultural parcels is a crucial element of the EU aid procedure, since it is first used by the farmer when applying for a grant and then the agency when checking the application, as the EU ensures the eligibility and transparency of the granting of area payments through the operation of this system. It should be pointed out that the EU payment for the agricultural parcel, i.e.: the basic unit of cultivated land shall always be paid to the user of the site and not to the owner of the land. (In case, the owner cultivates the area, he is entitled to claim the support.) The services provided by MePAR 
are based on geoinformatics, where the land to be subsidized shall be identified on orthophotos

A larger territorial unit than the agricultural parcel is known as the physical block [2], which includes several agricultural parcels whose borders are roads, canals, railways, forest edges, etc. They mostly cover areas with the same cultivation, but generally each parcel has different owners. Blocks have a unique national identifier, which helps to immediately find out all the data that applies to a block (e.g.: its location, its size, etc.). The borders of the block and its inner segments are recorded using state-of-the-art procedures (processing of air and space shots) and on-site data recording. Agricultural lands belonging to individual farmers can be identified on the electronic interface, and it is very easy to detect permanent terrestrial elements (e.g.: roads, buildings, canals, forests, etc.) on the aerial orthophoto background. Support requests are first checked by Magyar Államkincstár (Hungarian State Treasury), but field and remote sensing tests are also carried out during the pre-payment eligibility testing procedure. A renewed, i.e.: change monitoring, aerial survey of the whole territory of the country is carried out every three years, because only the third/quarter of the country is covered annually. [3]

In preparation for the EU funding period after 2014, the Mezögazdasági és Környezeti Információs Rendszer (MeKIR, Agricultural and Environmental Information System) was also developed in Hungary [4], which, like MePAR, through geographic identification by means of GIS systems has enabled coexisting different registry systems to work in a unified system. This can be perceived as a metadata database affecting the MePAR physical block data, land use data (e.g.: Natura 2000 data), state land data (NFA database), nature conservation and environmental land data, forest area information and livestock data (cattle, pigs, sheep, goats, poultry and horse).

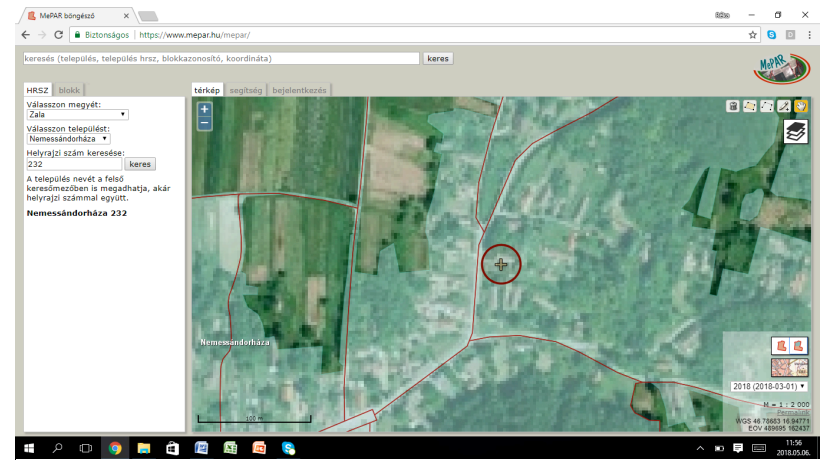

Figure 1 Displaying eligible land areas in MePAR (darker green)

\section{Digitizing the Agricultural Sector}

The Digital Agrarian Strategy (DAS, hereafter 'Strategy'), which is part of the Digital Welfare Program, agreed upon by the Government of Hungary, as a result of social consultation urges the digital education and training of the agricultural social classes in Hungary lagging behind the Western EU Member States, and in particular the introduction of innovation technology and further training systems through the so-called precision use of agricultural machines. The Strategy is based on exact, accurate knowledge of the production environment, data collection, database building, and development of applications that support automated interventions and decisions, and integration of all these devices. It assumes that the economic benefits of the IT development in the domestic agricultural sector are currently unused, and in the absence of integration cannot be efficiently operated, their systematic operation is necessary.

Surveys on the cost-cutting effects of precision agriculture have not yet been made in Hungary. However, EU analyses show that making machinery smart, tracking them, and automatic steering of vehicles results in savings of approximately $€ 2$ per hectare. [5] Informatics can connect consumers with producers through databases and analyses even on the longest product paths.

According to the creators of the Strategy, the main obstacle to the spread of IT solutions in domestic agriculture is human resources' lack of preparedness, their skills and attitudes. Taking into account the number of farms, the industry is lacking 3000 professionals who are familiar with both IT and agricultural processes, who could design and operate applications, who could educate and advise users. An additional policy barrier is the support policy itself, which does not consider agricultural innovation, the distribution of existing products and the necessary training and counselling a matter of priority. The regulatory environment defining agricultural production is inadequate because it does not take into account the emergence of new technologies and their economic impact, thus for example making it difficult to access national databases for business purposes and to use drones for production purposes. [6]

The Strategy blames the users' lack of abilities and skills, as well as the lack of regulation, support system, professional background systems and administrative systems, and their current functioning as an obstacle to the spread of agro-informatics developments.

It is worth mentioning the iMezö (belonging to iGazda) mapping software, which allows the farmer to draw over satellite images and aerial photographs to mark the areas of land he uses, which are stored in a separate layer and a panel can be assigned to these fields, thus identifying and linking the modules. 


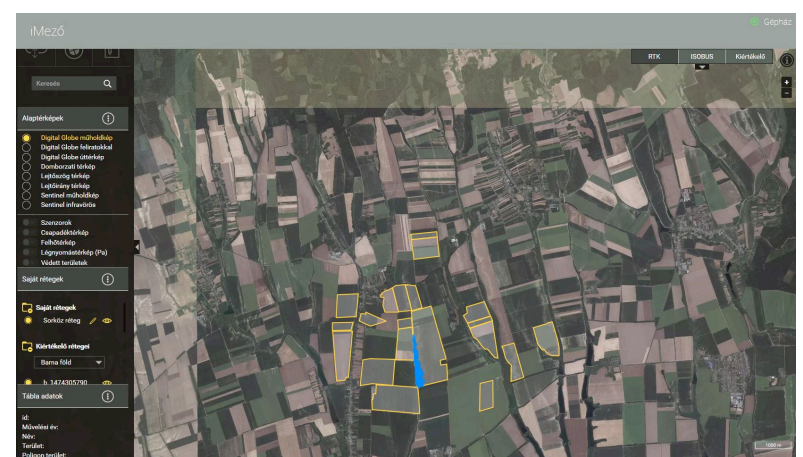

Figure 2 With iMező an area of land can be marked over satellite images and aerial photographs.

iGazda solutions are web-based, so they can be accessed on any device with an internet connection, such as a computer, tablet or smartphone. Its surface is transparent, anyone can handle it with a minimal knowledge of information technology. [7]

III. Developing the ICT competence of agricultural professionals with a view on regulations of EU land policy

I aim at identifying the cornerstones that require the training and further education of agricultural professionals through digital modernization of EU land policy regulations and by means of digital image processing devices.

Cornerstones:

$$
\begin{aligned}
& \mathrm{A} \text { - training of agricultural professionals } \\
& \mathrm{B} \text { - modernisation/digitization of EU land policy } \\
& \mathrm{C} \text { - harmonisation of processes }
\end{aligned}
$$

\section{A)}

In the last decade the equipment of agricultural professionals went through rapid development due to automation. These developments required professionals working in the sector concerned to acquire newer skills, resulting in efficiency, speed and quality performance.

The next step in this process has now appeared in agriculture, which means not only the modernisation of the tools used so far, but also the introduction of new ICT devices on a wider scale. These tools (e.g.: drones, tablets, robotics programming, metadata databases, AR/VR applications, etc.) necessitate the acquisition of completely new competencies for which a specific methodology is essential. These competencies include:

- interpretation of digital concepts and systems,

- $\quad$ management of ICT tools - gestures, Wi-Fi / Bluetooth connectivity, etc.,

- management and use of digital (space) data, meta-databases,

- $\quad$ interpreting and managing state surveys and processes provided by digital imaging,

- more complex vision - among tools and services,

\section{- digital design \\ - providing digital reporting data related to regulation, etc.}

In the development of the new methodology, considering the aging of the generation of professionals in the sector (note: the average age in Hungary is over 50 years), it is recommended to build up the training and further education with a tiered structure, which requires incremental and consecutive elements.

$$
\begin{array}{ll}
\text { - } & \text { frontal (tier 1), } \\
\text { - } & \text { blended learning (tier 2), } \\
\text { - } & \text { e-learning and m-learning (tier 3) }
\end{array}
$$

This is to realize the sensitization of professionals to the introduction of new ICT tools on an everyday basis.

It is also important that trainings and further education courses include practice-oriented elements and steps closely related to agricultural activities, as the effective acquisition of new knowledge can thus be assured to the candidate group.

The above-mentioned tiered training and further education structure also allows the advancement of the levels to be achieved in situ, i.e.: in the immediate surroundings of the professionals.

By developing this training system, it is also possible to provide training for professionals who are equally competent in agriculture and in using ICT devices of the sector.

\section{B)}

The modernisation of the EU land policy regulation, with regard to digital devices, including the achievements of digital image processing, is necessary, which is an ideal solution to ensure the convergence of Community interests.

Factors influencing the need to modernize regulations:

- uniform geopolitical objectives,

- establishing an effective agricultural support system,

- ensuring coherence between applied sectoral technologies and related regulations

- supporting globalization competitiveness.

The modernisation of regulation poses significant challenges to professionals, as not only the emerging new technological tools and procedures, but also the specific regulatory elements of nation states should be taken into account.

In view of all this, the elements of modernising the regulation process are the following:

- exploration

(regulations, ICT tools, current developments, practical needs, etc.)

- analysis

(impact of alternative regulations on the sector, qualification of necessary professionals, planning related costs, timing, etc.)

- implementation

(gradual introduction of new regulations, establishment of transitional provisions, support for training / tools, etc.) 
As a result of the new "digital" regulation, agricultural professionals with sufficient ICT knowledge can accomplish more accurate technical and economic planning and development with up-to-date data, ultimately resulting in the optimized allocation of agricultural resources at EU level and the convergence of community interests.

C)

The training of agricultural professionals and the harmonisation of modernization processes of EU land policy regulation are inevitable and necessary. The reason being that the training results in unnecessary extra costs, without modernizing proper regulation, and vice versa (see below).

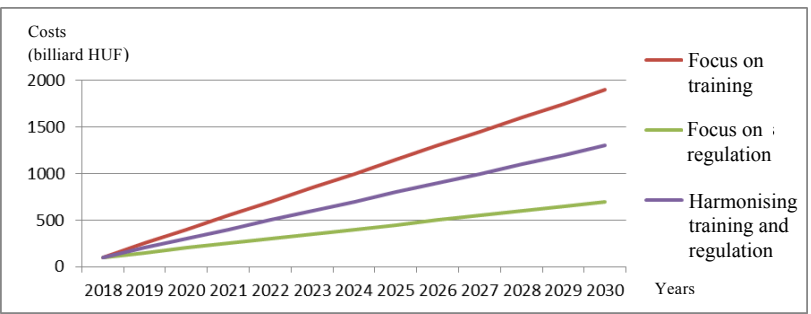

Figure 3 Change of modernisation and training costs (self-made figure)

With this in mind, we can state that if more emphasis is put on training, it can generate significant additional expenses, while regulation cannot track and support the professional procedures and services already in practical use (orange line).

In contrast, if regulation is given more emphasis, its introduction cost is remarkable, but its efficiency, effectiveness and usefulness on agricultural mechanisms are questionable as the level of knowledge and tools of professionals is not yet at the level to be achieved by the regulation (blue line).

In both cases, additional costs emerge that result in the ineffective use of resources and thus justify implementing the harmonisation of modernised regulations and sectoral training of professionals (yellow line).

\section{Suggestions}

Coordinating the training of agricultural professionals with the regulation and technological development is in line with the proposal of the Digital Agrarian Strategy, which proposes improvements in two areas, namely in the field of digital competence and the digital state, as follows. Laying down these principles, in my opinion, is an indispensable basis for practical implementation.

In the field of digital competence development, the knowledge and awareness development program provides basic knowledge and promotes the acquisition of conscious thinking and basic knowledge for the use of digital tools and applications; education development program gives already conscious users the opportunity to look at user level opportunities, be able to identify their own development directions and communicate with agricultural IT specialists; counselling and development program provides answers to the questions of producers and other actors of agrobusiness through individual, customized counselling.

In the field of digital state development, the regulatory development program includes the modification of the regulatory environment needed to increase the efficiency of digital economy; the professional server systems development program provides state-based digital services (e.g.: weather forecast) and access to public data from both IT and financial side; the purpose of the epublic administration development program is to enable agribusiness players to minimize their administrative resources for public administration and subsidy management. The development policy program, on the one hand, supports the financing of individual development programs and the planning and progress on the other hand. [8]

\section{REFERENCES}

[1] An area of land according to section a) (4) 67 of the Regulation (EU) No 1306/2013 of the European Parliament and of the Council of 17 December 2013 on the financing, management and monitoring of the common agricultural policy and repealing Council Regulations (EEC) No 352/78, (EC) No 165/94, (EC) No 2799/98, (EC) No 814/2000, (EC) No $1290 / 2005$ and (EC) No $485 / 2008$

[2] An area of land according to sections (2)-(6) 32 of the Regulation (EU) no 1307/2013 of the European Parliament and of the Council of 17 December 2013 establishing rules for direct payments to farmers under support schemes within the framework of the common agricultural policy and repealing Council Regulation (EC) No 637/2008 and Council Regulation (EC) No 73/2009

[3] https://www.mepar.hu/8-menupontok (5 May 2018)

[4] In the framework of project EKOP-1.2.19-2012-2013-0001 with a grant of HUF 1350000000 .

[5] http://ivsz.hu/agrarinformatika/digitalis-agrar-strategia/ (5 May 2018)

[6] http://ivsz.hu/agrarinformatika/digitalis-agrar-strategia/ (5 May 2018)

[7] https://www.agroinform.hu/gepeszet/a-precizios-adatokathasznositja-az-igazda-rendszere-31919-002 (5 May 2018)

[8] http://ivsz.hu/agrarinformatika/digitalis-agrar-strategia/ (6 May 2018) 